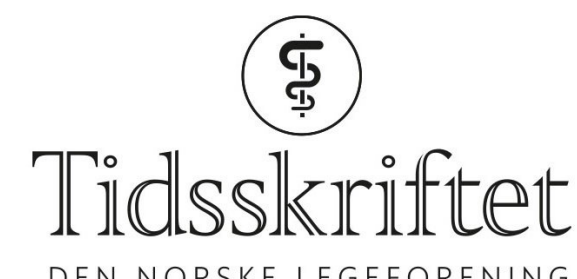

DEN NORSKE LEGEFORENING

\title{
Tina Jakobsson
}

MINNEORD

OLE JACOB NILSEN

HEGE SAGSTUEN HAUGNES

ELISABETH LANGE

HILDE SKUTERUD WIK

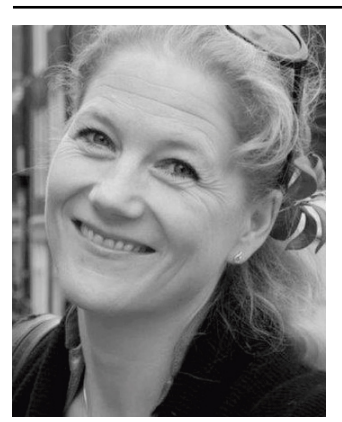

Vår kjære studievenn fra PK-92, Tina Jakobsson, døde brått og uventet 29. april 2020, bare 47 år gammel.

Vi begynte sammen på medisinstudiet i Oslo høsten 1992 og ble raskt kjent med Tina og hennes smittende latter og humør. I studietiden var Tina med på det meste og kjente de fleste. Hun var særdeles sosial, gjestfri og initiativrik og var den perfekte vertinne enten vi var på fest i Tinas bofellesskap eller på hyttetur til familien Jakobssons fine hytte på Geilo. Vi ble også inkludert i Tinas familie og vennegjeng og fikk bli kjent med mange av de flotte menneskene hun hadde rundt seg. Etter den prekliniske delen hadde fire av oss noen måneder sammen på reise i Vietnam, Laos og Thailand. Vi har også vært på sommerutveksling i Egypt.

Tina var en dyktig og engasjert student, men hadde også en stor nysgjerrighet på livet utenfor studiet. Hun tok en etterlengtet permisjon, som ble tilbrakt i et trekkfullt kollektiv i Paris med jobb på kafé. Vi var selvfølgelig på besøk. Tre av oss ble gjenforent på sykehuset i Harstad, hvor vi hadde en fantastisk turnustid sammen. Så pass fint var det at vi ble værende i kortere eller lengre tid etterpå.

Tina jobbet som fastlege, sist ved Centrum Fastlegegruppe. Det er rørende, men ikke overraskende, å lese minneordene fra mange av hennes fornøyde pasienter. Med sin varme og omsorg tok hun like godt vare på pasientene sine som på familie og venner.

Vi har mistet en fantastisk venn som vi så gjerne skulle hatt med oss videre. Det er ikke til å 
fatte at Tina ikke lenger er blant oss. Våre tanker går til Tinas sønn Jonatan, som hun var så uendelig stolt av, til mannen Christian, hennes mamma Wenche, brødrene Thomas og Kim og resten av familien og de mange vennene.

Publisert: 17. august 2020. Tidsskr Nor Legeforen. DOI: 10.4045/tidsskr.20.0538

(C) Tidsskrift for Den norske legeforening 2020. Lastet ned fra tidsskriftet.no 